\title{
SOSIALISASI SOP (STANDAR OPERATING PROCEDURE) PADA PENGOBATAN TRADISIONAL PATAH TULANG DI CITAPEN
}

\author{
Diah Fatma Sjoraida, Rully Khairul Anwar, dan Edwin Rizal. \\ Fakultas Ilmu Komunikasi, Universitas Padjadjaran \\ E-mail: diah.fatma@unpad.ac.id
}

\begin{abstract}
ABSTRAK. Salah satu jenis pengobatan tradisional yang diminati oleh masyarakat saat ini adalah pengobatan tradisional patah tulang. Hasil studi pendahuluan di Bandung Barat, terdapat setidaknya enam pengobatan tradisional yang merupakan pengobatan ahli tulang. Namun, penyedia layanan di enam pengobatan ahli tulang tersebut mengaku belum pernah mendapatkan sosialisasi khusus untuk memberikan teknis pengobatan tulang secara "benar" dan "sama". Maka dibutuhkan kegiatan sosialisasi Standar Operating Procedure (SOP) yang bertujuan untuk menambah wawasan dan memberikan pengetahuan terbaru tentang pemanfaatan informasi terutama bagi masyarakat yang lebih mempercayai pengobatan secara tradisional daripada pengobatan medis. Metode pelaksanaan dilakukan dengan beberapa tahap, yakni persiapan, pelaksanaan sosialisasi yang terdiri dari penyajian materi, penugasan, refleksi dan evaluasi. Jumlah peserta sudah hampir memenuhi target, dengan animo peserta cukup tinggi menghasilkan diskusi mengalir dan simulasi dilaksanakan dengan sangat antusias. Peserta terdiri dari terapis pengobatan patah tulang dan masyarakat Citapen. Dari hasil refleksi kegiatan, diperoleh kesimpulan bahwa peserta menganggap kegiatan ini sangat positif. Diharapkan dengan adanya kegiatan sosialisasi tersebut dapat berkontribusi terhadap pengambilan keputusan masyarakat mengenai patah tulang dan metode pengobatannya.
\end{abstract}

Kata kunci: pengobatan tradisional, pengobatan patah tulang, sosialisasi, standar operating procedure, terapis patah tulang

\section{PENDAHULUAN}

Pengobatan tradisional merupakan salah satu upaya pengobatan atau perawatan cara lain di luar ilmu kedokteran atau ilmu keperawatan, yang banyak dimanfaatkan oleh masyarakat dalam mengatasi masalah kesehatan (Keputusan Menteri Kesehatan Republik Indonesia Nomor 1076/Menkes/Sk/Vii/2003 Tentang Penyelenggaraan Pengobatan Tradisional Menteri Kesehatan Republik Indonesia, 2003). Pengobatan tradisional di Indonesia, memiliki peminatnya tersendiri. Hal tersebut dapat dibuktikan dengan masih bertahannya para pengobat tradisional dalam menjalankan klinik pengobatannya. Salah satu jenis pengobatan tradisional yang diminati oleh masyarakat saat ini adalah Pengobatan tradisional patah tulang. Hasil studi pendahuluan di Bandung Barat, terdapat setidaknya enam pengobatan tradisional yang merupakan pengobatan ahli tulang. Namun, penyedia layanan di enam pengobatan ahli tulang tersebut mengaku belum pernah mendapatkan pelatihan khusus untuk memberikan pengobatan tulang tersebut. Rata-rata penanganan yang diberikan di enam pengobatan tradisional ahli tulang tersebut sama, biasanya penyedia layanan akan membebat tulang yang patah dengan kain yang diolesi minyak tertentu. Ada pula yang "mengobati" bagian yang trauma dengan cara menarik bagian tulang. Tindakan yang dilakukan biasanya tergantung dari jenis trauma tulang yang dialami pasien. Memilih metode tradisional seperti bengkel tulang, secara medis sebenarnya masih terbilang aman, selama kasus yang ditangani masih bersifat ringan atau sederhana (Kompas, 2008). Selain itu, biasanya terapis pengobatan patah tulang tersebut mendapatkan keterampilannya dengan cara turun temurun. Di Kabupaten Bandung Barat, tepatnya daerah Citapen terdapat beberapa bengkel tulang yang dibangun berjajar di pinggir jalan raya dan setelah ditelusuri, terapis pengobatan patah tulang tersebut masih keluarga besar. Artinya, keterampilan yang dimiliki para terapis saat ini adalah hasil warisan dari leluhurnya. Bengkel tulang Citapen, sudah cukup dikenal oleh masyarakat, bukan hanya masyarakat sekitar Bandung saja namun sudah meluas sampai berbagai provinsi di Indonesia. Bahkan para atlet nasional yang cedera pun sering terlihat melakukan pengobatan tradisional di bengkel patah tulang Citapen.

Meskipun pengobatan secara medis jauh lebih modern, namun pengobatan secara tradisional masih menjadi primadona bagi masyarakat Indonesia. Berdasarkan hasil penelitian sebelumnya dapat disimpulkan bahwa motif masyarakat masih memilih pengobatan tradisional khususnya bengkel patah tulang. Hal tersebut disebabkan karena adanya motif ekonomi yang dimana masyarakat lebih menyukai pengobatan biaya murah, lalu motif sosial yang dimana masyarakat mengikuti saran dari lingkungan terdekatnya dalam hal ini adalah tetangga, teman ataupun keluarga dan yang terakhir adalah motif psikologis dimana ada kepercayaan lebih pada pengobatan tradisional dibandingkan pengobatan medis. Kepercayaan masyarakat yang tinggi terhadap pengobatan tradisional patah tulang, harus didukung dengan informasi dan pengetahuan yang mumpuni. Maka dari itu diperlukan suatu kegiatan untuk memperkenalkan proses pengobatan tradisional dilengkapi dengan penanganan terhadap berbagai kondisi tulang yang dirasa bermasalah. Salah satunya adalah kegiatan sosialisasi SOP (Standar Operating Procedure) pengobatan tradisional patah tulang di daerah Citapen, Kabupaten Bandung Barat.

\section{METODE}

Metode kegiatan PKM ini terdiri dari beberapa tahapan, yakni tahap persiapan, pelaksanaan sosialisasi dan evaluasi kegiatan. 


\section{Persiapan.}

Tahap ini merupakan tahap awal sebelum pelaksanaan kegiatan sosialisasi. Dalam tahap ini ada beberapa kegiatan yang dilakukan, yakni; Koordinasi internal yang dilakukan oleh Tim untuk merencanakan pelaksanaan secara konseptual, operasional, serta job description. Lalu penentuan dan rekruitment peserta sosialisasi. Pembuatan instrumen PKM, seperti lembar presensi, angket, lembar kerja, dsb. Dan terakhir persiapan konsumsi, publikasi, lokasi, dokumentasi.

2. Pelaksanaan Sosialisasi

Tahap ini merupakan tahap sosialisasi sekaligus proses pendampingan kepada peserta sosialisasi. Pelaksanaan sosialisasi ini mencakup beberapa hal berikut:

a) Penyajian materi. Materi yang disajikan terkait dengan literasi informasi yang bisa dijadikan sebagai media pembelajaran di sekolah. Penyajian ini diploting dalam satu hari tatap muka. Adapun materi yang disampaikan adalah konsep dasar SOP dan teknik pengobatan tradisional patah tulang. Setelah proses pemberian materi selesai akan dilakukan proses pendampingan para peserta. Proses pendampingan ini akan dilakukan selama satu minggu dengan melibatkan mahasiswa.

b) Penugasan. Pada akhir materi peserta diberi kuesioner sesuai materi yang telah tersaji. Dalam hal ini untuk menggali penyerapan dan pemahaman materi serta melihat kreativitasnya dalam berkarya. Dalam praktik ini para peserta ditugaskan untuk menjawab pertanyaan mengenai kepercayaan terhadap pengobatan tradisional, dan pemahaman terhadap SOP yang disajikan. Tim pengabdi kemudian mendampingi semua proses kegiatan dan memnerikan instruksi atau arahan pada hal-hal yang masih dianggap rumit oleh para peserta.

c) Refleksi dan penutupan kegiatan sosialisasi. Di akhir kegiatan peserta dan Tim melakukan refleksi hasil sosialisasi dan para peserta juga memberikan evaluasi akan sosialisasi ini. Pada tahap ini antara peserta dan tim PPM sama-sama mengevaluasi jawaban yang telah dibuat. Tim PPM memberikan masukan dan arahan kembali terutama member penegasan kepada jawaban yang masih memiliki kelemahan. Setelah semua kegiatan yang telah direncanakan terlaksana, ketua tim PPM menutup program dan memberikan pesan kepada segenap peserta untuk menerapkan apa yang telah didapatkannya. Diharapkan pada PKM yang akan datang program ini dapat dilanjutkan kembali dan dapat menjangkau jumlah masyarakat lebih banyak lagi.

3. Evaluasi kegiatan Sosialisasi

Evaluasi kegiatan PKM ini dilakukan dengan beberapa cara. Evaluasi hasil dilihat dari tugas praktik para peserta yang ada. Hasil praktiknya dinilai dan hal itu menggambarkan keberhasilan materi yang telah disajikan. Selain itu, secara proses juga dicermati kinerja dan kesertaan para peserta. Di akhir kegiatan Tim menjaring data kebermaknaan program pada para peserta.

\section{HASIL DAN PEMBAHASAN}

Pengobatan tradisional adalah salah satu upaya pengobatan atau perawatan cara lain diluar ilmu keterapisan atau ilmu keperawatan, mencakup obat dan cara pengobatannya, yang mengacu kepada pengetahuan, pengalaman dan keterampilan yang diperoleh secara turun temurun, berguru, magang atau pendidikan/pelatihan baik yang asli maupun yang berasal dari luar negri dan diterapkan sesuai norma yang berlaku dalam masyarakat.

Pengobatan tradisional menurut KEPMENKES no 36 tahun 2009 membagi 2 macam pengobatan tradisional yang ditinjau dari cara pengobatannya, antara lain pengobatan melalui keterampilan dan pengobatan dengan ramuan. Terdapat beberapa kondisi pasien yang datang untuk melakukan pengobatan tradisional patah tulang, diantaranya:

1. Kondisi patah tulang hingga remuk/hancur.

Pasien yang datang ke pengobatan tradisional memiliki kondisi yang parah, tulang yang berada di telapak kaki sudah hancur/remuk sehingga tidak bisa berfungsi dengan baik, bahkan terapis pun sudah melakukan diagnosis bahwa kakinya harus segera diamputasi sebelum membusuk. Kondisi tersebut terjadi karena kecelakaan, dan kakinya terlindas oleh truk pengangkut barang. Namun pasien tersebut tidak mau menuruti apa yang dikatakan terapis, lalu mencoba untuk berobat ke pengobatan tardisional patah tulang. Terapis melakukan pengobatan terhadap pasien tersebut dengan cara, mengusap kaki tersebut, lalu membungkus kaki yang sudah hancur tersebut dengan kain. Dan begitu seterusnya hingga 2 bulan lamanya. Perlu diketahui, tulang kaki akan tersambung dengan sendirinya dan terapis hanya membantu melalui teknik pembungkusan yang tepat. Teknik pengobatan dalam kasus ini, terapis tidak menggunakan sistim pijat/urut dikarenakan tulang kaki tersebut sudah hancur dan tidak bisa disambung dengan pijatan.

2. Kondisi patah tulang kaki hingga menembus daging.

Pasien tersebut mengalami kecelakaan saat berjalan di pinggir jalan raya, tiba-tiba ada motor terlempar dan menghantam kakinya. Sehingga kaki pasien tersebut mengalami patah tulang hingga menembus daging. Adapun teknik pengobatannya adalah dilemaskan dulu urat syaraf yang terdapat di kaki, tangan dan telinga dengan cara dipijat dengan lembut, setelah itu baru dilakukan tindakan. Tindakannya adalah dengan pemasangan kayu yang dibalut parutan umbi-umbian agar tulang yang patah tadi dapat tersambung kembali. Adapun proses pengobatannya memerlukan waktu 2 
bulan, hingga pasien tersebut dapat berjalan kembali. Maka dari itu diperlukan suatu aturan yang menjaga proses pengobatan agar tidak keluar dari jalur yang semestinya. Aturan tersebut dapat berupa standar operating procedure atau SOP.

Standard Operating Procedure (SOP), atau "Prosedur" adalah dokumen yang lebih jelas dan rinci untuk menjabarkan metode yang digunakan dalam mengimplementasikan dan melaksanakan kebijakan dan aktivitas organisasi seperti yang ditetapkan dalam pedoman. Pada dasarnya, prosedur merupakan instruksi tertulis sebagai pedoman dalam menyelesaikan sebuah tugas rutin atau tugas yang berulang (repetitif) dengan cara yang efektif dan efisien, untuk menghindari terjadinya variasi atau penyimpangan yang dapat mempengaruhi kinerja perusahaan secara keseluruhan (Soemohadiwidjojo, 2014).

Setiap perusahaan membutuhkan sebuah panduan untuk menjalankan tugas dan fungsi setiap elemen atau unit di perusahaan. Standar Prosedur Operasional adalah sistem yang disusun untuk memudahkan, merapikan dan menertibkan pekerjaan. Meskipun, pengobatan tradisional bukan sebuah lembaga dan memiliki teknik pengobatan yang berbeda, namun perlu diadakannya SOP agar dapat meminimalisir kejadian yang buruk.
Setiap terapis memiliki teknik pengobatan yang berbeda tergantung dari kondisi patah tulang yang dialami. Selain itu masing-masing terapis pun memiliki ciri khas dalam teknik pengobatannya, antara lain:

1. Pengobatan Tradisional. Ini dilakukan oleh terapis dengan menggunakan racikan tradisional dari alam, seperti umbi-umbian dalam proses pengobatannya. Umbi-umbian tersebut dihaluskan lalu di oleskan pada bagian yang cedera, lalu dipijat secara halus, dan terakhir dilakukan pemasangan perban dan kayu agar tulang yang patah tidak tekena goncangan.

2. Pengobatan biomedis. Dilakukan oleh klinik yang menggunakan teknologi medis dalam teknik pengobatannya, seperti menggunakan obat antibiotik untuk membnatu pasien dalam mengurangi rasa sakit serta foto rontgen untuk membantu memudahkan pasien mengenali kondisi patah tulang yang dialami.

3. Pengobatan intergrasi. Dilakukan oleh klinik yang menggabungkan pengobatan tradisional dengan pengobatan medis, seperti bantuan obat kimia, bantuan teknologi rontgen dan digabung dengan obat tradisional yang merupakan racikan alami.

Dalam Keputusan Menteri Kesehatan Republik Indonesia Nomor 1076/MENKES/SK/VII/2003 tentang Penyelenggaraan Obat Tradisional Pasal 18 dikatakan

Tabel 1. SOP Pengobatan Tradisional Patah Tulang

\begin{tabular}{|c|c|c|}
\hline No & Kegiatan & Keterangan \\
\hline 1 & Pengertian & Pengobatan tradisional adalah suatu tindakan pengobatan dengan cara, alat dan obat secara tradisional \\
\hline 2 & Tujuan & $\begin{array}{l}\text { Membantu meringankan keluhan dan gejala pasien } \\
\text { Membantu proses kesembuhan pasien }\end{array}$ \\
\hline 3 & Karakteristik Pasien & $\begin{array}{l}\text { Pasien yang mempunyai keluhan patah tulang dan membutuhkan penanganan dan pengobatan secara } \\
\text { tradisional }\end{array}$ \\
\hline 4 & Karakteristik Terapis & $\begin{array}{l}\text { Terapis adalah orang yang mengikuti pelatihan khususnya dalam pengobatan patah tulang dan } \\
\text { ditunjuk secara langsung oleh karuhun sebelumnya. Untuk menjadi terapis tidaklah sembarang orang } \\
\text { bisa, namun memerlukan ritual khusus yang wajib dijalani calon terapis. Antara lain: puas mutih } \\
\text { selama } 30 \text { hari dengan pantangan makan hanya satu kepal ubi rebus, minum satu gelas, tidak boleh } \\
\text { berkomunikasi dan berinteraksi dengan siapapun, dan harus selalu wirid (mengucapkan kalimat- } \\
\text { kalimat Alloh). Setelah sukses melakukan ritual, maka sang guru akan mewariskan ilmunya kepada } \\
\text { calon terapis tersebut. }\end{array}$ \\
\hline 5 & Alat dan bahan & $\begin{array}{l}\text { 1. Tempat tidur } \\
\text { 2. Selimut } \\
\text { 3. Minyak untuk memijat } \\
\text { 4. Tempat cuci tangan } \\
\text { 5. Handuk bersih } \\
\text { 6. Meja } \\
\text { 7. Kursi } \\
\text { 8. Kayu untuk penyangga tulang patah } \\
\text { 9. Umbi-umbian (singkong, ubi, aci) } \\
\text { 10. Air minum } \\
\text { 11. Alat untuk parut umbi tersebut }\end{array}$ \\
\hline 6 & Prosedur/ langkah & $\begin{array}{l}\text { 1. Terapis bertanya kepada pasien mengenai apa yang dikeluhkan } \\
\text { 2. Terapis menjelaskan kepada pasien mengenai kondisi patah tulangnya } \\
\text { 3. Terapis menjelaskan cara pengobatan yang akan dilakukan serta resiko yang akan terjadi } \\
\text { 4. Setelah pasien setuju, terapis mulai melakukan tindakan pengobatan sesuai dengan kondisi pasien } \\
\text { 5. Terapis mengobservasi segala tindakan yang telah dilakukan } \\
\text { 6. Terapis bertanya pada pasien mengenai perbedaan sebelum di lakukan pengobatan hingga setalah } \\
\text { melakukan pengobatan } \\
\text { 7. Terapis menjelaskan pantangan-pantangan yang harus diikuti agar cepat sembuh } \\
\text { 8. Terapis menyarankan pada pasien agar melakukan pengobatan lagi sesuai dengan kondisi patah } \\
\text { tulang tersebut. } \\
\text { 9. Jika dirasa sudah sembuh, pasien tidak perlu lagi melakukan pengobatan. }\end{array}$ \\
\hline & Dokumen terkait & $\begin{array}{l}\text { 1. Biodata pasien } \\
\text { 2. Rekam medis pasien. }\end{array}$ \\
\hline
\end{tabular}


Tabel 2. Kegiatan Sosialisasi SOP Pengobatan Tradisional Patah Tulang

\begin{tabular}{|c|c|c|c|c|}
\hline \multirow{2}{*}{ No } & \multirow{2}{*}{$\begin{array}{l}\text { Rencana } \\
\text { Kegiatan }\end{array}$} & \multicolumn{3}{|c|}{ Keterlibatan dalam Kegiatan } \\
\hline & & Dosen dan Terapis & Mahasiswa & Peserta \\
\hline 1 & $\begin{array}{l}\text { Tahap } \\
\text { Persiapan }\end{array}$ & $\begin{array}{l}\text { 1. Melakukan persiapan materi penyuluhan. } \\
\text { 2. Menyiapkan bahan-bahan praktek untuk } \\
\text { penelusuran informasi }\end{array}$ & $\begin{array}{l}\text { 1. Melakukan koordinasi dengan } \\
\text { pihak kecamatan. } \\
\text { 2. Mempersiapkan surat } \\
\text { undangan }\end{array}$ & $\begin{array}{l}\text { Memberikan masukan tentang } \\
\text { berbagai potensi yang harus } \\
\text { dikembangkan }\end{array}$ \\
\hline 2 & $\begin{array}{l}\text { Tahap } \\
\text { Pelaksanaan }\end{array}$ & $\begin{array}{l}\text { 1. Memberikan materi ceramah } \\
\text { 2. Memberi sosialisasi } \\
\text { 3. Melakukan evalusi kegiatan }\end{array}$ & $\begin{array}{l}\text { 1. Menyiapkan acara sosialisasi } \\
\text { 2. Membantu kegiatan sosialisasi }\end{array}$ & $\begin{array}{l}\text { Membantu pelaksanaan kegiatan } \\
\text { sosialisasi }\end{array}$ \\
\hline 3 & $\begin{array}{l}\text { Tahap } \\
\text { Penyusunan } \\
\text { dan } \\
\text { Penggandaan } \\
\text { Laporan }\end{array}$ & $\begin{array}{l}\text { Melakukan penyusunan laporan dan } \\
\text { pengandaan }\end{array}$ & $\begin{array}{l}\text { Membantu menyiapkan data data } \\
\text { penunjang }\end{array}$ & $\begin{array}{l}\text { Melakukan konsultasi dengan para } \\
\text { peserta untuk mengetahui respons } \\
\text { terhadap kegiatan yang telah } \\
\text { dilaksanakan }\end{array}$ \\
\hline
\end{tabular}

bahwa, pengobat tradisional dapat memberikan obat tradisional yang diproduksi oleh industri obat tradisional (pabrikan) yang sudah terdaftar serta memiliki nomor pendaftaran, dan obat tradisional racikan (Menteri Kesehatan Republik Indonesia, 2003). Obat tradisional hasil racikan sendiri diperbolehkan oleh Menteri Kesehatan Republik Indonesia.

Implementasi program PKM dimulai dengan melakukan koordinasi dengan para terapis untuk menyusun jadwal pelaksanaan kegiatan, menyiapkan tempat kegiatan, menyiapkan sarana prasarana pendukung dan sebagainya. Koordinasi dengan pihak para terapis sudah dilakukan melalui berbagai alat komunikasi yaitu: telepon dan surat menyurat. Kemudahan penggunaan teknologi informasi ini sangat membantu untuk sosialisasi, pengiriman undangan dan konfirmasi kehadiran peserta. Secara umum proses kegiatan sosialisasi SOP di Citapen Kabupaten Bandung Barat akan dijelaskan dalam tabel 2.

Materi sosialisasi mengenai konsep dasar SOP, dan teknik pengobatan tradisional khususnya patah tulang dengan menggunakan informasi interaktif. Struktur materi sosialisasi tersebut di atas disusun secara praktis dan sederhana serta dilengkapi dengan contoh sehingga mudah dicerna. Hal ini juga mengacu dan disesuaikan dengan kebutuhan peserta. Materi kegiatan sosialisasi ini merupakan materi yang sangat luas, sehingga mustahil dapat diberikan semua dalam kegiatan sosialisasi ini. Oleh karena itu pelaksana mencoba menyusun materi yang sederhana, ringkas dan mampu mendukung kegiatan belajar mengajar serta disesuaikan dengan ketersediaan waktu kegiatan dan sarana pendukungnya.

Sebagai puncak kegiatan sosialisasi adalah forum group discussion dengan masyarakat. Keberhasilan suatu kegiatan sosialisasi juga ditentukan bukan saja oleh materi dan instruktur tetapi juga oleh metode dan media pembelajarannya. Sosialisasi adalah pendidikan bagi orang dewasa sehingga memerlukan pendekatan yang pas, yaitu dengan multi metode dan multi informasi. Dalam hal ini selain metode konvensional yang biasa digunakan yaitu ceramah dan tanya jawab, tetapi dilakukan secara mendalam dengan brain storming dan diskusi mendalam, sehingga partisipasi peserta akan meningkat dan tidak menjemukan,selain itu juga digunakan informasi berupa ilustrasi foto. Dengan informasi yang demikian maka kegiatan sosialisasi menjadi dinamis dan sangat menarik dan tidak menjemukan. Hal ini juga menjadi salah satu metode dan informasi yang menarik dan berhasil memberikan pemahaman dan kemampuan yang sangat baik bagi peserta. Penerapan multi metode dan multi informasi dalam kegiatan sosialisasi ini menjadikan PKM berlangsung secara dinamis, peran serta dan partisipasi peserta meningkat, terbukti dengan banyaknya peserta yang mengemukakan pertanyaan, pendapat dan usul dalam kajian setiap pokok bahasan. Hal ini muaranya adalah terbentuknya pemahaman peserta terhadap materi sosialisasi secara kompehensif.

Kesan dan tanggapan peserta dalam sosialisasi ini sangat positif, hal ini ditunjukkan dengan presensi kehadiran, bahasan dan tanggapan waktu penyajian materi dengan berbagai pertanyaan dan diskusi tentang materi, serta harapan agar sosialisasi ini masih ditindaklanjuti dengan kajian yang lebih luas dan mendalam. Evaluasi peserta berupa beberapa aspek, meliputi kehadiran, partisipasi di kelas, penyusunan makalah dan presentasi makalah.

\section{SIMPULAN}

Setelah dilakukan kegiatan sosialisasi kepada masyarakat diperoleh beberapa kesimpulan yaitu peserta mendapat pengetahuan mengenai standar operting procedure (SOP), peserta mendapat pengetahuan mengenai teknis pengobatan tradisional, dan peserta mendapat pengetahuan mengenai SOP pengobatan tradisional khususnya patah tulang. Setelah mendapatkan pengetahuan-pengetahuan tersebut, harapannya masyarakat akan memiliki lebih banyak pertimbangan dalam pengambilan keputusan mengenai cidera patah tulang yang diderita.

\section{DAFTAR PUSTAKA}

Menteri Kesehatan. Keputusan Menteri Kesehatan Republik Indonesia Nomor 1076/ Menkes/SK/ VIIII/2003 tentang penyelenggaraan pengobatan tradisional, Jakarta 2003. 
Soejono, Sri K, Lamsudin R. Ghofir A. 1999. Pengobatan konvensional dan pengobatan komplementer. Yogyakarta: Universitas Gadjah Mada

Suryani. 2005. Komunikasi Terapeutik: Teori Dan Praktik. Jakarta: EGC.
Keputusan Menteri Kesehatan Republik Indonesia Nomor 1076/Menkes/Sk/Vii/2003 Tentang Penyelenggaraan Pengobatan Tradisional Menteri Kesehatan Republik Indonesia (2003). Indonesia. Retrieved from file:///C:/Users/Acer ES1432/Downloads/1_2003_1076-Menkes-SKVII-2003_ot.pdf 